\title{
FRACTURE SYSTEMS IN THE YOUNGER GRANITE ROCKS AROUND FOBUR, NORTHERN NIGERIA: PRODUCT OF RESIDUAL STRESS?
}

O. I. EJEH AND C. F. UGBE

Received 14, May 2009; Revision Accepted 31, August 2009)

\begin{abstract}
Outcrop-scale fractures and associated veins found in the Younger Granite rocks around Fobur, Northern Nigeria were studied in relation to similar structures in their host rocks (Migmatites-gneisses -quartzite complex). Fractures and veins attitude (strike and dip) data were collected across the study area and subjected to graphical and stereographic analyses. The result revealed a predominant N-S strike with variations in the NE-SW and NW-SE directions; and others trending in the E-W direction (dip joints). Field observations indicated neither deformation of joints planes nor distortion of joint directions which confirmed that the jointing occurred in an anorogenic setting. Nevertheless, the joint structural trend in the Younger Granite rocks replicated those found in the surrounding orogenic basement rock exposures. This could reflect the likely existence in the host Migmatite-gneiss-quartzite complex imposed residual stresses of the Pan African event that were not fully relieved. These ancient stress systems possibly helped to orient the fractures and other structures in a later emplaced Younger Granite complex in a fashion similar to the enclosing basement complex rocks.
\end{abstract}

KEY WORDS: Residual Stress, Fractures, Younger Granites, Fobur, Nigeria.

\section{INTRODUCTION:}

Fractures are the most ubiquitous structures in the crust of the earth, occurring in a wide range of rock types and tectonic settings. They control the physiography of many spectacular landforms and play an important role in the transport of fluids and mineralization. Fractures along which there has been no appreciable displacement parallel to the fracture and only slight movement normal to the fracture plane are joints. They are extensional, with fracture plane oriented parallel to $\sigma_{1}$ and $\sigma_{2}$ and perpendicular to $\sigma_{3}$ (Hatcher, 1995). It is a fact that joints reveal rock strain accommodated by brittle fractures, and the establishment of reliable relationships between them and their causes can provide the structural geologist with important tools for inferring the state of stress and mechanical behavior of rocks (Pollard and Aydin, 1988). Although much work has been done on the structures of the Younger Granites, especially with respect to ring dykes, cone sheets, volcanic cauldrons, and high level granite plutons (Turner, 1989), very little is known about the patterns of fractures and the stress fields that produced them. This paper examines the structural attitudes of fractures in the Younger Granite rocks around Fobur (northwestern part of sheet 169, Maijuju) and their course of emplacement.

The study area lies between latitudes $9^{\circ} 46^{\prime}$ and $9^{\circ} 56^{\prime} \mathrm{N}$ and longitudes $9^{\circ} 00^{\prime}$ and $9^{\circ} 05^{\prime} \mathrm{E}$, covering an area of $216.85 \mathrm{~km}^{2}$ (fig.1) .

\section{Geological Setting}

The Younger Granites of Jos Plateau, Nigeria, are made up of alkaline feldspar granites in association with rhyolites, minor gabbros and syenites. They occur mainly as sub-volcanic intrusive complexes of ring dykes and related annular and cylindrical intrusions. The Granites have been variously mapped and elucidated by a number of workers: Ajakaiye (1970); MacLeod et al (1971); Jacobson and MacLeod, (1972); Turner and Webb (1974); Buchanan et al (1971); Bowden et al (1989), Bowden (1970); Bowden and Turner (1974); Ajakaiye et al (1985); lbe et al (1985); Imeokparia (1985); Ike and Sakoma (1985), Badejoko (1986); Turner (1986, 1989); Abaa (1991); Aina and Olarewaju (1992); Mücke (2003), and Ogunleye et al (2005). The great

O. I. Ejeh, Geology Department, Delta State University, Abraka, Nigeria.

C. F. Ugbe, Geology Department, Delta State University, Abraka, Nigeria. 


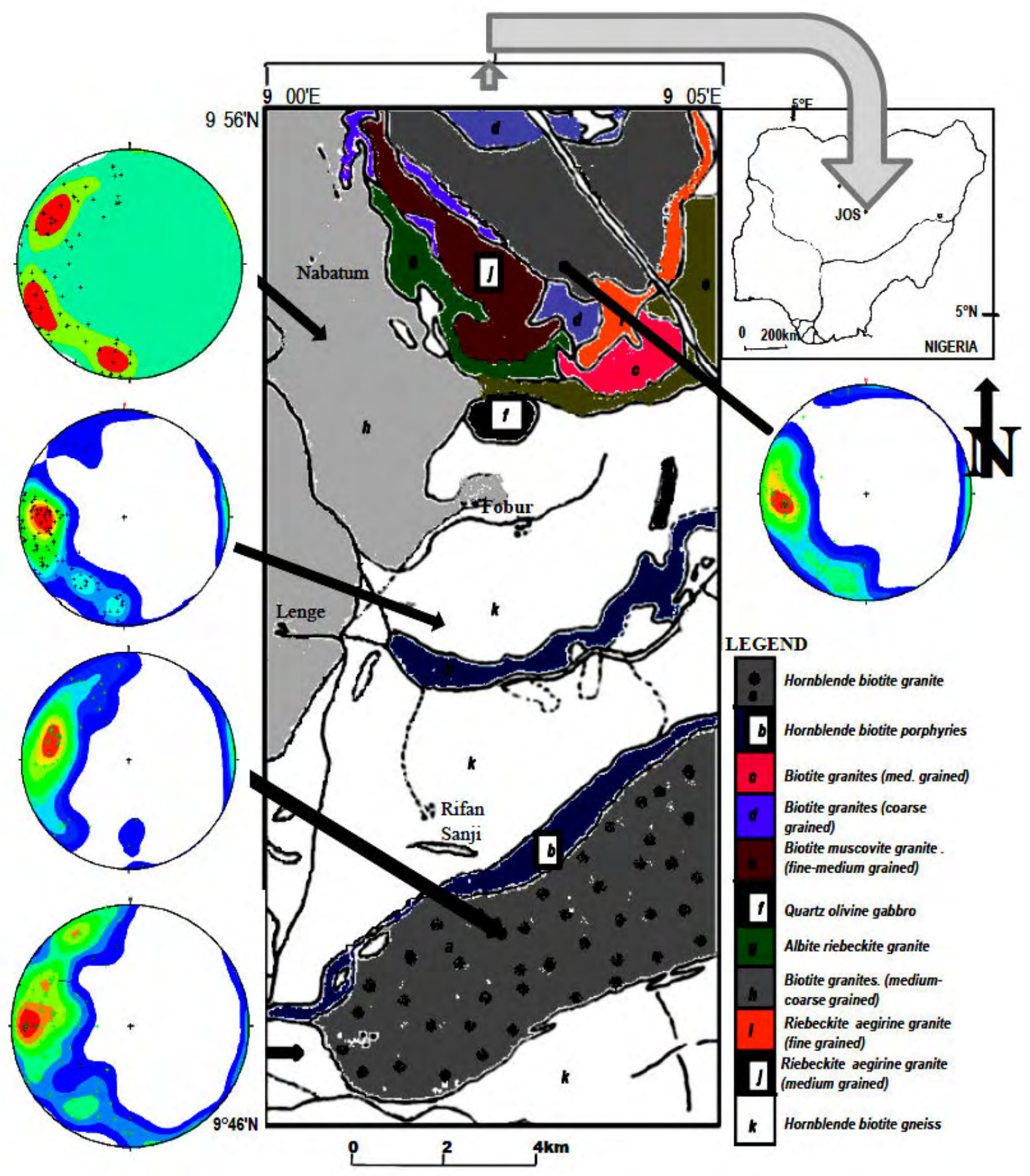

Fig. 1. Location/geological map (modified after Geological Survey of Nigeria, sheet 169) of the study area with stereographic projection of joints (Schmidt net, lower hemisphere). Insert is a map of Nigeria indicating study area. 
variety of different rock types (ring complexes) and the economic importance of the region have given impetus to much of the geologic interests. Throughout most of its history, the Precambrian crust (basement) of Nigeria has been subjected to series of essentially similar cycles of events. Each cycle was marked by deposition of supra crustal sediments and volcanics, succeeded by deformation and metamorphism, basement reactivation and emplacement of granitic intrusions. These developments are products of four orogenies which affected the Nigerian basement during the Precambrian. These are: Liberian (2700ma), Eburnean (2200ma), Kibaran (1300-1400ma) and Pan African (450-1100ma). Each of these orogenies left its structural imprints on the basement rocks due to the poly-phase deformation (Ekwueme, 1994). Other authors are of the opinion that due to the pervasive nature of the last tectono-thermal event (Pan African) earlier structures were obliterated (Mc Curry,1971; Rahaman, 1976). Although the Pan African event was pervasive, it did not completely homogenize the rocks in the basement, as such traces of earlier structures remained (Grant, 1978; Onyeagocha and Ekwueme, 1982; Ekweme, 1987; Oluyide, 1988). Structures produced by the Pan African are reported to trend North-South $(\mathrm{N}-\mathrm{S})$ to North EastSouth West (NE-SW, 0-30 ) while earlier events produced structures trending $50-70^{\circ}, \mathrm{E}-\mathrm{W}$ and NW-SE (Mullan, 1979; Grant, 1978; Ekwueme, 1987).

The deformed basement appeared to have exerted a measure of structural control in the emplacement of the Younger Granites of Nigeria. This emplacement is said to have been controlled by the $\mathrm{N}-\mathrm{S}$ trending fractures (Ibe et al, 1985; Udoh, 1988). Other controls include ring faulting, and cauldron subsidence. Their emplacement is completely anorogenic and of Jurassic age (160-170ma) (Badejoko, 1988; Ogunleye et al, 2005; Jacobson et al, 1963). This is in sharp contrast with the calc-alkaline Older Granites of the basement that are Pan African in age ( $\approx 650 \mathrm{ma}$ ) and orogenic in origin (Van Breeman and Bowden, 1973).

\section{Materials and Methods:}

Field Study and Data Treatment: The field study involved a detailed geologic mapping on a scale of 1:10,000. The observed rock types were described on the basis of lithological properties. Measurements of azimuths (strikes and dips) of structural features especially those of joints and veins were systematically taken and recorded. About one thousand measurements of strikes and dips of joints and strike directions of veins were taken on the rocks of the area. These data were statistically analysed and plotted using StereoStat geological software. The generated rose diagrams and stereogram plots are indicated in figures 1 and 2 . The study area was divided into five structural domains. Each domain is represented by a rose diagram and contoured stereogram (fig. 1). Point diagrams on an equal-area net generally expressed as contour maps were prepared for each of the small areas (figs. 1and 2).

\section{Description of the Lithological Units:}

The study area consists of gneisses forming the basement complex rocks which have been intruded by per alkaline Younger Granite rocks. The gneisses are mainly hornblende biotite gneiss. They are low lying, outcropping mostly in ephemeral stream channels. This lithology underlies about $40 \%$ of the study area (fig. 1). In some localities this rock is dissected by quartz veins. The Younger Granite rocks include Hornblende biotite granite, Albite riebeckite granite, and Riebeckite aegirine granites.

Granites form prominent hills which have been well exposed by weathering and erosion and often appear rugged. There is a tendency for horizontal sheeting developed in the weathered 


\begin{tabular}{|c|c|c|c|}
\hline $\begin{array}{l}\text { Composite Rose } \\
\text { Diagrams }\end{array}$ & $\begin{array}{l}\text { Lower hemisphere } \\
\text { stereonets }\end{array}$ & Descriptions & Interpretations \\
\hline & & $\begin{array}{l}\text { Orientations of fractures } \\
\text { on Biotite granites. } \\
\text { fractures structural trend } \\
\text { is mostly NNW-SSE with } \\
\text { variations in the NE-SW } \\
\text { and E-W. Total number } \\
\text { of readings taken: } 248 \text {. }\end{array}$ & $\begin{array}{l}\text { Strike joints }(\mathrm{N}-\mathrm{S}) \text { are } \\
\text { dominant with fracture } \\
\text { planes parallel to } \sigma_{1} \text { and } \\
\sigma_{2} \text { and perpendicular to } \\
\sigma_{3} \text { (least principal stress } \\
\text { axis).The E-W direction } \\
\text { is the prevailing } \\
\text { tensional axis of the } \\
\text { stress field. }\end{array}$ \\
\hline & & $\begin{array}{l}\text { Orientations of Foliations } \\
\text { on Hornblende biotite } \\
\text { gneiss. Foliation structural } \\
\text { trend is mostly N-S with } \\
\text { variations in the NW-SE } \\
\text { and E-W. Total number } \\
\text { of readings taken: } 96 .\end{array}$ & $\begin{array}{l}\mathrm{N}-\mathrm{S} \text { orientation is } \\
\text { dominant, which is } \\
\text { replicated by the } \\
\text { fractures of the } \\
\text { Younger granitic } \\
\text { intrusives. }\end{array}$ \\
\hline & & $\begin{array}{l}\text { Orientations of fractures } \\
\text { on Hornblende biotite } \\
\text { granites. fractures } \\
\text { structural trend is mostly } \\
\text { NNE-SSW, NNW-SSE } \\
\text { with variations in the NE- } \\
\text { SW and E-W. Total } \\
\text { number of readings taken: } \\
252 \text {. }\end{array}$ & $\begin{array}{l}\text { Strike joints (N-S) are } \\
\text { dominant with fracture } \\
\text { planes parallel to } \sigma_{1} \\
\text { and } \sigma_{2} \text { and } \\
\text { perpendicular to } \sigma_{3} \\
\text { (least principal stress } \\
\text { axis). }\end{array}$ \\
\hline & & $\begin{array}{l}\text { Orientations of fractures } \\
\text { on Hornblende biotite } \\
\text { gneiss. fractures structural } \\
\text { trend is mostly N-S with } \\
\text { variations in the NE-SW } \\
\text { Total number of readings } \\
\text { taken: } 150 \text {. }\end{array}$ & $\begin{array}{l}\text { Strike joints }(\mathrm{N}-\mathrm{S}) \text { are } \\
\text { dominant with fracture } \\
\text { planes parallel to } \sigma_{1} \\
\text { and } \sigma_{2} \text { and } \\
\text { perpendicular to } \sigma_{3} \\
\text { (least principal stress } \\
\text { axis). }\end{array}$ \\
\hline & & $\begin{array}{l}\text { Orientations of fractures } \\
\text { on Biotite granites. } \\
\text { fractures structural trend } \\
\text { is mostly NE-SW, NW- } \\
\mathrm{SE} \text {, and E-W with minor } \\
\text { variations in the N-S. } \\
\text { Total number of readings } \\
\text { taken: } 258 \text {. }\end{array}$ & $\begin{array}{l}\text { Both strike }(\mathrm{N}-\mathrm{S}) \text { and } \\
\text { dip joints(E } \mathrm{W}) \text { are } \\
\text { dominant with fracture } \\
\text { planes parallel to } \sigma_{1} \text { and } \\
\sigma_{2} \text { and perpendicular to } \\
\sigma_{3} \text { (least principal stress } \\
\text { axis), replicating earlier } \\
\text { tectonic episodes. }\end{array}$ \\
\hline
\end{tabular}

Fig. 2. Joint orientation data collected in the study area. Composite rose diagrams show the average strike direction of fractures. Lower hemisphere stereonets show the orientations of pole to fractures (joints) as observed in the field (measured). Contours are plotted at intervals of two and highlight the clustering of poles. 
Granite outcrops (fig.3A), a feature that produced the spectacular towers of perched boulders which add to the scenic attraction of the Fusa Hills. Contacts between the basement rocks and the granite intrusives are usually not very distinct. Xenoliths of basement rocks which are trapped in the granitic rocks appear to have been formed through magmatic 'stoping'.

\section{Structural Geology}

Both planar and linear structures were mapped in the study area.

Planar Structures: While fractures appeared on all rock types, foliations were exhibited only by basement gneissic rocks. Foliations observed on the gneisses are depicted by alternation of leucocratic and melanocratic bands of felsic and mafic minerals respectively that are products of metamorphic deformation and migmatitic processes that affected the basement. Poor exposures

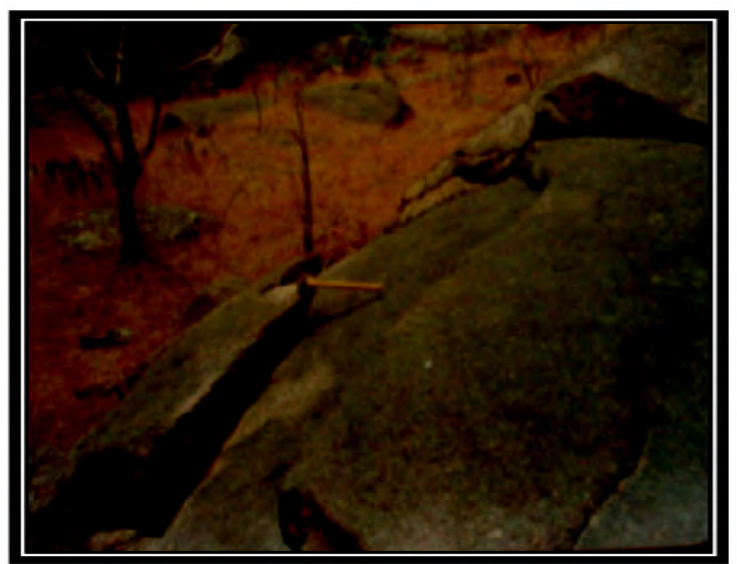

(A)

Fig. 3. Fracture patterns present on Younger Granites. (A) Horizontal sheeting found on some outcrops. (B) A dissected abutting relationship created by joint sets. (C) Sets with average strikes of $005^{\circ}$ and $101^{\circ}$. Note the abutting relationship between the quartz veins ( $Q T Z V)$ and the joints set almost at $090^{\circ}$ to each other. of these low lying gneisses allowed only a few measurements (about one hundred readings) of strikes and dips of foliations. Statistical analyses indicate the dominant foliation directions as NNE-SSW, NNW-SSE, and NW-SE (fig.2). Foliation dips ranged from $75^{\circ}$ to $80^{\circ}$.

Fractures: Fractures are common to all rock types of the study area. They ranged from tight $(0-0.1 \mathrm{~cm})$ to open joints $(0.1-5 \mathrm{~cm})$, and vary in length from $10 \mathrm{~m}$ to several metres. Most of the joints occur in sets giving the rock exposures a dissected, blocky or fragmented appearance (fig.3B and C). In terms of their attitudes some of the joints are vertical, while others vary from inclined to horizontal (fig.3A). Although, most of the joints have planer surfaces, no visible sign of movement parallel to them were recognized. In some cases, slight or major movements at right angles to the joints produce open joints.

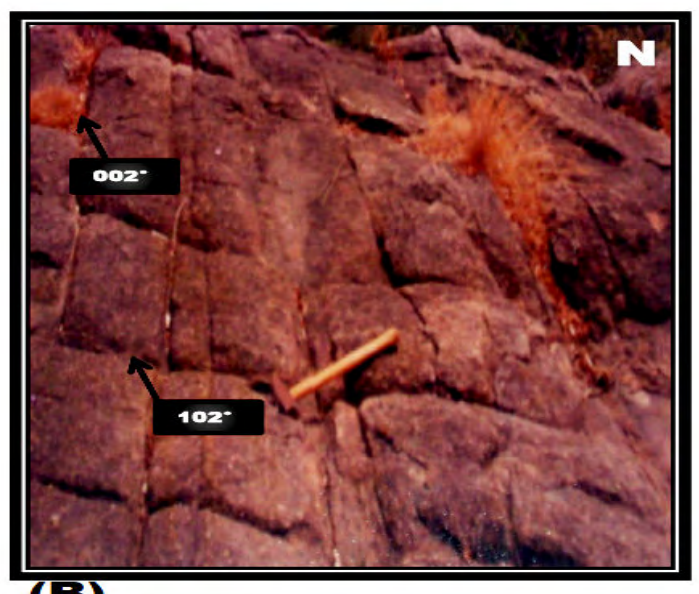

(B)

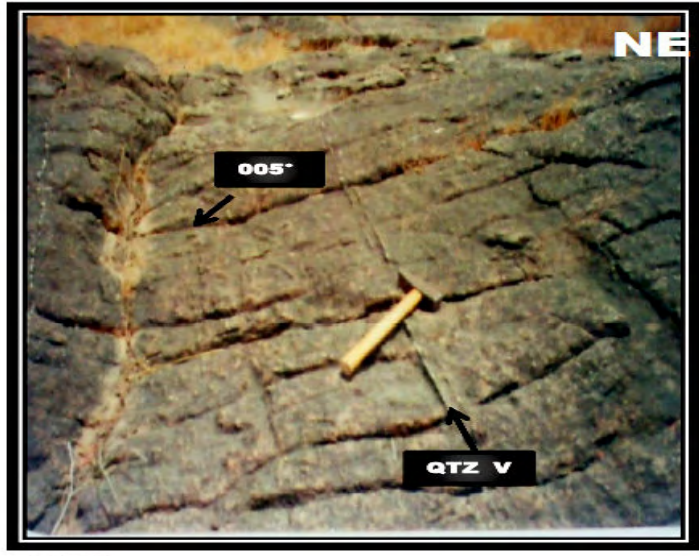

(C)
Quartz veins occur in abundance on the granitic rocks. Some of these quartz veins cross-cut joint sets which suggest that the veins are younger. It is obvious that the joints were formed first before the veins (fig.3C). The mechanism by which veins formed is of special interest to our understanding crustal deformation. Ramsay (1980) presented evidences that many if not all of extension veins are formed by an accretionary process involving the formation of a narrow fracture or joint followed by filling of the open space by crystalline material(s) through a mechanism he termed "crackseal". Most of the quartz veins proved more resistant to weathering than their host rocks (fig. 3C).

\section{Discussion:}

The Younger Granites of Nigeria are per alkaline in nature and anorogenic in origin. However, 
they show similar fracture trends with the orogenic basement rocks. The structural orientation of the basement rocks is an expression of structural deformation relicts or imprints traceable to the various thermo-tectonic events that they have undergone. In this work, attention is directed mostly at fractures, and veins. Generally these structures are secondary or mostly tectonic in origin. Statistical analyses of the structures measured in the field revealed that they strike predominantly N-S and dip westerly (fig. 2). This structural attitude mimics those found in the surrounding basement rocks. Previous studies have also revealed the dominance of such north- southerly trend in the Nigerian basement (Oluyide, 1988). The jointing recorded by the Younger Granites of the study area could be termed as post tectonic or anorogenic because neither deformation of the joint planes nor distortion of the directions was observed, as would be expected of joints formed as a result deformational episode(s).

For the fact that tectonic joints are quantitative and manifestation of the direction of the operative forces during deformation, they give a clue to the possible stress distribution in a deformed area (Adekoya, 1978). In discussing the origin of tectonic joints, Price (1959) was of the view that they are surface expressions of residual stresses released after deformation. It is important to note that joints form in response to the variations in magnitude and direction of the prevailing stress field. The strike joints $(\mathrm{N}-\mathrm{S})$ have fracture planes parallel to $\sigma_{1}$ and $\sigma_{2}$ and perpendicular to $\sigma_{3}$ (least principal stress axis) (fig.4A). In this case E-W direction is the prevailing tensional axis of the stress field. For the dip joints $(E-W)$, the fracture plane is parallel to the $\sigma_{1}$ and $\sigma_{2}$ and $N-S$ is the prevailing tensional axis of the stress field (fig.4B).

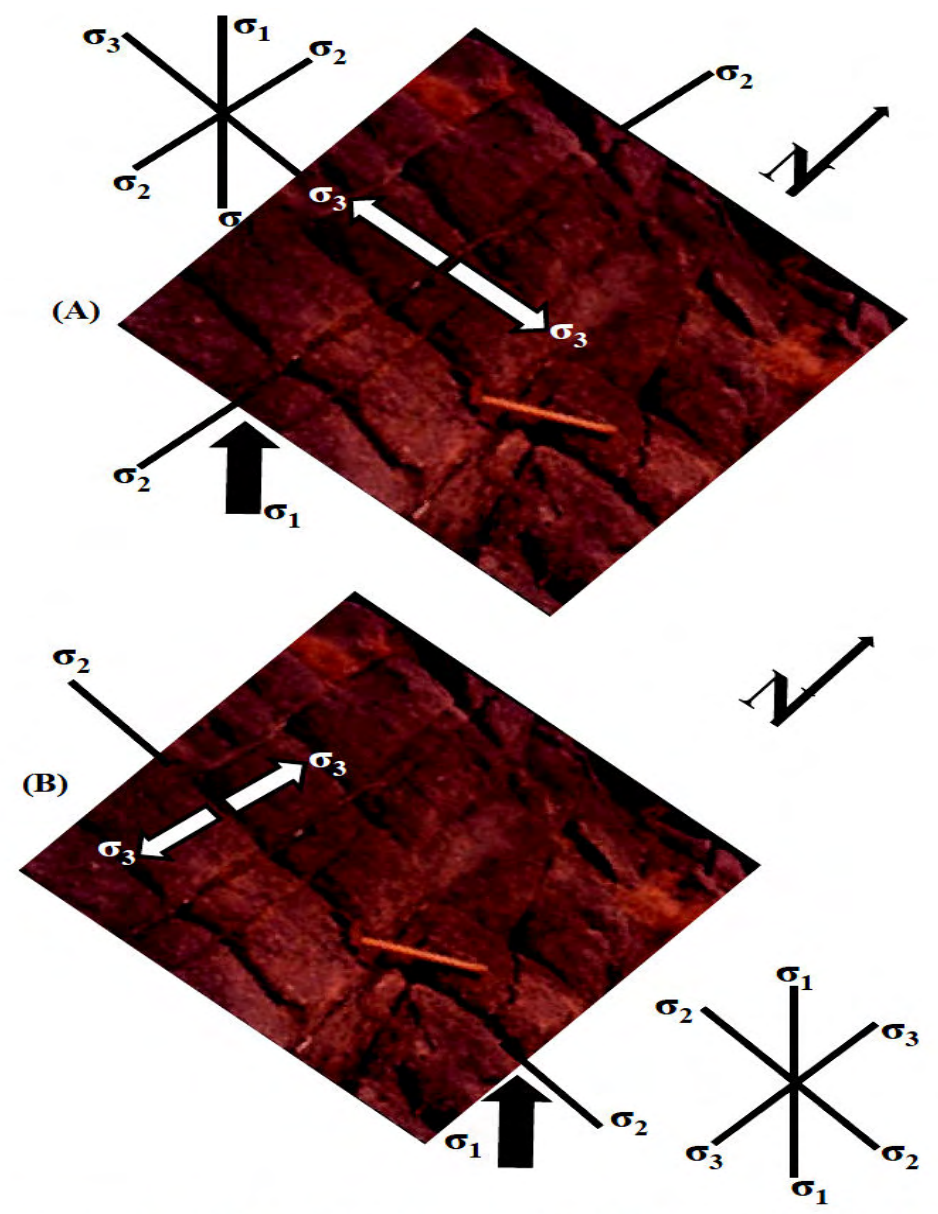

Fig. 4. Approximate Joint orientations related to principal stress axes in (A) Strike Joint stress field and (B) Dip Joint stress field. 
The Pan African event has been described as the most penetrative and wide spread deformational episode producing N-S to NE-SW trending structures. Such structural trend is dominant and wide spread in the Nigerian basement (Ekwueme, 1994). Pre-Pan African deformational episodes produced the E-W and NW-SE trending structures. Earlier it has been mentioned that the observed field structures are similar in orientation and type to the basement structures that are widely known to be orogenic. This is an indication that they are products of similar stress fields operating at different geologic times. A plausible explanation for this is the likely existence of residual stresses. These may be tectonic stresses that were not fully relieved. Such remaining ancient stresses serve to orient the joints and other structures in a manner replicating that of the basement. This supports the view earlier held by Udoh (1988) that the Younger Granites' emplacement was controlled by the structures of the basement rocks. Clearly, the Younger Granites of Nigeria though have not undergone any orogenic event, their structures especially joints are of residual stresses induced by past orogenic events. The interpretations here presented are considered preliminary. It is hoped that subsequently further field mapping and the use of satellite imagery will enable definitive conclusions.

\section{ACKNOWLEDGEMENT}

We appreciate Dr. S.B. Olobaniyi, who carefully read the manuscript of this paper and made useful suggestions and directives.

\section{REFERENCES}

Abaa, S.I., 1991. Hydrothermal fluids responsible for the formation of precious minerals in the Nigerian Younger Granite Province. Mineralium Deposita 26 (1): pp.34-39.

Adekoya, J. A.,1978. A Note on Jointing in the Basement Complex of the Ibadan Area, Oyo State, Nigeria. Journal of Mining and Geology.14 (1): pp.48-52.

Aina, A. and Olarewaju, V.O., 1992. Geological interpretation of aeromagnetic data in some parts of north-central Nigeria. Journal of African Earth Sciences 14 (1), pp.103-109.

Ajakaiye, D. E., 1970. Gravity measurements over the Nigerian Younger Granites Province. Nature. 225, pp. 50-52.

Ajakaiye, D. E., Hall, D.H. and Miller, T.W., 1985. Interpretation of aeromagnetic data across the central crystalline shield area of Nigeria. Geophysical Journal- Royal Astronomical Society 83(2), pp.503-517.

Badejoko, T. A., 1986. The Petrogenesis of the Younger Granites of Nigeria. Journal of African Earth Sciences 5(3), pp.233-242.

Badejoko, T. A., 1988. Unusual titanium-rich oxide mineral from per alkaline granites of Kigom Complex, northern Nigeria. Journal of African Earth Sciences 7(4), pp.703-706.
Bowden, P., 1970. Origin of the Younger Granites of northern Nigeria. Contr.Mineral. and Petrol. 25, pp.153-162.

Bowden, P. and Turner, D.C., 1974. Peralkaline and associated ring complexes in the Nigerian-Niger Province, West Africa. In: The Alkaline Rocks, $\mathrm{H}$. Serensen (ed) John Willey, New York. pp.330-351.

Bowden, P., Whitley, J.E. and Van Breeman, O., 1989. Geochemical studies on the Younger Granites of northern Nigeria. In: Geology of Nigeria $\left(2^{\text {nd }}\right.$ ed). C.A. Kogbe (ed), Rock View Nig. Ltd, Jos.pp.209-225.

Buchanam, M.S., MacLeod, W.N., Turner, D.C., Berridge, N.G. and Black, R., 1971. The Geology of the Jos Plateau. Younger Granites Complexes. Bull. Geol. Surv. Nigeria. 2(32): 160P.

Ekwueme, B. N., 1987. Structural orientations and Precambrian deformational episodes of Uwet area, Oban Massif, S.E. Nigeria. Precambrian Research. 34, pp.269-389.

Ekwueme, B. N., 1994. Structural features of southern Obudu Plateau, Bamenda Massif, S.E. Nigeria: Preliminary interpretations. Journal of Mining and Geology 30(1): pp.45-59.

Grant, N. K., 1978. Structural distinction between a metasedimentary cover and underlying basement in 600my old Pan African domain of north western Nigeria, West Africa. Geol. Soc. Am. Bull. 89. pp.50-58.

Hatcher, R. D. Jr., 1995. Structural Geology: Principles, Concepts, and Problems. Prentice-Hall, Inc. Englewood Cliffs, New Jersey 07632. 525P.

Ibe, K.K., Ajakaiye, D.E. and Ojo, S. B., 1985. Gravity interpretations of the Zaranda Younger Granite ring complex, Nigeria. Journal of African Earth Sciences 3(1-2): pp.253-259.

Ike, E. C. and Sakoma, E. M., 1985. Field Geology of the Dago ring complex, Nigeria. Journal of African Earth Sciences 3(1-2):pp.97-100.

Imeokparia, E. G.,1985. Geochemical evolution of the Jarawa Younger Granite complex and its related mineralization, northern Nigeria. Geological Magazine 122(2):pp.163-173.

Jacobson, R.R.E. and MacLeod,W.N. 1972. Geology of the Liruei, Banke and adjacent Younger Granite Ring complexes. Bull. Geol. Surv.Nigeria (33): $111 \mathrm{p}$.

Jacobson, R.R.E., Snelling, N.J. and Truswell, J.F. 1963. Age determinations in the Geology of Nigeria, with special reference to the Older and Younger Granites. Overseas Geol. Miner. Resources. 9, pp.168-182.

MacLeod, W.N., Turner, D.C., Wright, E.P., Berridge, N.G., and Black, R., 1971. The Geology of the Jos Plateau. Bull. Geol. Surv. Nigeria. (32);112p. 
Mc Curry, P., 1971. Pan African Orogeny in northern Nigeria. Geol. Soc.Am.Bull. 82, pp.3251-3262.

Mücke, A., 2003. Fayalite, pyroxene, amphibole, annite and their decay products in mafic clots within Younger Granites of Nigeria: Petrography, mineral chemistry and genetic implications. Journal of African Earth Sciences 36 (1-2): pp.55-71.

Mullan, H.S.1979. Structural distinction between a metasedimentary cover and an underlying basement in the 600my old Pan African domain of northwestern Nigeria, West Africa: Discussion. Geol. Soc.Am.bull. 90, pp.983-984.

Ogunleye, P.O., Ike, E.C., and Garba, I., 2005. Geochemical characteristics of the niobium-rich arfvedsonite granites, Younger Granites Province of Nigeria. Chemie de Erde 65(3): PP.279-296.

Oluyide, P.O.1988. Structural trends in the Nigerian basement complex. In: Precambrian Geology of Nigeria. Oluyinde, P.O.(ed).Geol. Surv. Nigeria publ. pp.93-98.

Onyeagocha, A.C. and Ekweme, B. N., 1982. The PrePan African Structural features of north central Nigeria. Journal of Mining and Geology 9, pp.74-77.

Price, N. J., 1959. Mechanics of jointing in rocks. Geol. Mag.96,pp.146-167.

Pollard, D. D. and Aydin, A., 1988. Progress in understanding joints over the past century. Geol. Soc. Amer.Bull.,10,pp.1181-1204.

Rahaman, M. A., 1976. Progressive polyphase metamorphism in pelitic schists around Aiyetoro, Oyo state, Nigeria. Journal of Mining and Geology 13,pp.33-44.
Ramsay, J. G., 1980. The Crack-seal mechanism of deformation. Nature 284,pp.135-139.

Turner, D. C., 1986. Magma distribution and crustal extension in the Nigerian Younger Granites Province: evidence from the Wase area. Journal of African Earth Sciences 5 (3):pp.234-247.

Turner, D. C.,1989. Structure and Petrology of the Younger Granite ring complexes. In: Geology of Nigeria $\left(2^{\text {nd }}\right.$ ed.). C.A. Kogbe (ed), Rock View Nig. Ltd, Jos.pp.175-190.

Turner, D. D. and Webb, P. K., 1974. The Daura igneous complex, northern Nigeria; a link between the Younger Granites districts of Nigeria and south Niger. Jour. Geol. Soc.130 (1): pp.71-77.

Udoh, A. N., 1988. An interpretation of satellite imageries of Nigeria $7^{\circ} 40^{\prime} \mathrm{N}$. In: Precambrian Geology of Nigeria. Oluyide, P.O. (ed). Publ. Geol, Surv. Nigeria.pp.99-102.

Van Breeman, O. and Bowden, P., 1973. Sequential age trends for some Nigerian Mesozoic granites. Nature Physical Sciences, 242 pp.9-11. 